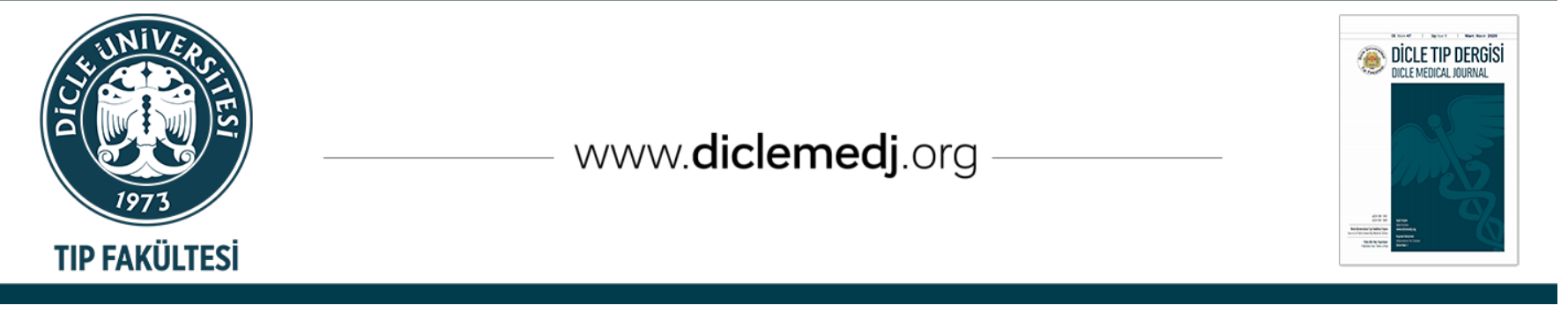

Özgün Araștırma / Original Article

\title{
Çocuklarda torakoport yardımlı laparoskopik apendektomi sonuçlarımız
}

\author{
Erol Basuguy ${ }^{1}{ }_{1}$, Mehmet Hanifi Okur ${ }^{D_{1}}$, Serkan Arslan ${ }^{i}{ }_{1}$, Bahattin Aydoğdu ${ }^{i}{ }_{1}$, Sevinç Akdeniz ${ }^{\left(D_{2}\right.}$, \\ Mustafa Azizoğlu iD 1 \\ 1 Dicle Üniversitesi Tıp Fakültesi Çocuk Cerrahisi Abd. Diyarbakır, Türkiye
}

2 Şırnak Devlet Hastanesi Çocuk Cerrahisi Şırnak, Türkiye

Geliş: 27.07.2020; Revizyon: 28.08.2020; Kabul Tarihi: 04.09.2020

$\ddot{0} \mathbf{z}$

Amaç: Açık, klasik multiport laparoskopi ve single insizyon laparoskopik cerrahinin (SILS) dezavantajlarının daha az olduğu torakoport yardımlı laparoskopik apendektomi deneyimlerimizi sunmayı amaçladık

Yöntemler: Çalışmada 2018 Ocak ve 2019 Aralık yılları arasında Dicle Üniversitesi Tıp Fakültesi Çocuk Cerrahi kliniğinde akut apandisit nedeniyle apendektomi yapılan hastaların verileri geriye doğru incelendi. Hastaların cinsiyeti, yașı, başvuru şikayetleri, tanı yöntemleri, laboratuvar tetkikleri, yapılan işlem, uygulanan tedavi yöntemleri ve hastanede kalış süreleri değerlendirildi. USG' de net olarak ayırt edilemeyen şüpheli bulgular izlenen ve ek patolojiler olabileceği düşünülen hastalara kontrastlı Bilgisayarlı Tomografi (BT) istendi. Operasyondan bir gün sonra hastanın kliniği uygunsa oral başlandı. Takiplerde herhangi bir problemi olmayan hasta önerilerle taburcu edildi. Bir hafta sonra hastalar patoloji sonuçları ile kontrole çağırıldılar. Oluşan komplikasyonlar kaydedildi.

Bulgular: Çalıșmamızda 177'si (\%63,7) erkek, 101'i (\%36,3) kız olmak üzere toplam 278 hasta vardı. Hastaların yaș ortalaması 11.6 (2-17) idi. Hastaların bașlıca semptomları: Karın ağrısı \%93.1 (n:260), iștahsızlık \%79,1 (n:220), bulantı \%26,9 (n:75), kusma \%16,9 (n:47) ve ateş \%4 (n:12) idi. Hastaların laboratuvar tetkiklerinde 209 (\%75,2) hastanın WBC' si yüksekti. CRP yüksekliği 218 (\%78,4) hastada tespit edildi. USG' de 235 (\%84) hastada anlamlı bulgular izlendi. BT çekilen 16 hastanın ise 14'ünde (\%5,03) apandisitle uyumlu bulgular izlendi. Hastaların tamamına ameliyata torakoport yardımlı laparaskopi ile başlandı. İşlem 250 (\%89,2) hastada torakoport yardımlı laparoskopik apendektomi olarak tamamlandı. Beş hastada 2. port, 10 hastada 3. port ihtiyacı oldu. On üç hastada laparoskopik işlem sonlandırıldı ve açık cerrahiye geçildi. Hastaların ortalama yatış süresi 1.7 (1-4) gün idi. Komplikasyon olarak 4 hastada brid ileus, 3 hastada yara yeri enfeksiyonu, 1 hastada umblikal herni gelişti ve cerrahi olarak düzeltildi. Brid ileus gelișen hastaların 3'ü konservatif olarak, birisi cerrahi olarak düzeltildi.

Sonuç: Torakoport yardımlı laparaskopik apendektomi minimal invaziv bir yöntem olup kozmetik, maliyet, cerrahi işlemin kolaylı̆̆ı, ağrı, hastanede yatış süresinin azlığı ve düşük komplikasyon gibi avantajları ile kullanılmasını önermekteyiz

Anahtar kelimeler: Torakoport, apendektomi, laparaskopi, çocuklar

DOI: 10.5798/dicletip.800307

Correspondence / Yazışma Adresi: Erol Basuguy, Dicle Üniversitesi Tıp Fakültesi Çocuk Cerrahisi Abd. Diyarbakır, Türkiye e-mail: erbas.80@hotmail.com 


\title{
Our results of thoracoport-aided laparoscopic appendectomy in children
}

\begin{abstract}
Objective: We aimed to present our experiences with thoracoport-assisted laparoscopic appendectomy, which has fewer disadvantages than open, conventional multiport laparoscopic and single-incision laparoscopic surgery (SILS).

Methods: In study, the data of patients, who underwent appendectomy for acute appendicitis between January 2018 and December 2019 in the Pediatric Surgery Clinic of Dicle University Faculty of Medicine Hospital, were retrospectively analyzed. Patients' gender, age, admission complaints, diagnostic methods, laboratory tests, procedure, treatment methods and length of hospital stay were evaluated. Contrast-enhanced Computed Tomography (CT) was ordered for patients with unclear and suspicious findings on the US and who were considered to have additional pathologies. One day after the operation, the patient was initiated on oral nutrition, if the clinic was appropriate. The patient with no problems in the follow-up was discharged with recommendations. One week later, the patients were invited to follow-up with pathology results. The complications that occurred were recorded

Results: Our study included a total of 278 patients, 177 (63.7\%) males, and 101 (36.3\%) females. The mean age of the patients was 11.6 years (range, 2-17 years). The main symptoms of the patients were abdominal pain 93.1\% (n: 260), anorexia 79.1\% (n: 220), nausea $26.9 \%$ (n: 75), vomiting 16.9\% (n: 47), and elevated fever 4\% (n: 12). In the laboratory tests of the patients, 209 (75.2\%) patients had high elevated WBC. CRP elevation was noted in 218 (78.4\%) patients. The US examination of 235 (84\%) patients was significant. Of the 16 patients who underwent CT, 14 (5.03\%) had findings consistent with appendicitis. The surgery was started with a thoracoport-assisted laparoscopy in all patients. In $250(89.2 \%)$ patients, the procedure was completed as a thoracoport-assisted laparoscopic appendectomy. Five patients required a second port and 10 patients required a third port. In 13 patients, the laparoscopic procedure was terminated and converted to open surgery. The mean length of hospital stay of the patients was 1.7 days (range 1-4 days). In terms of complications, 4 patients developed brid ileus, 3 patients developed wound infection, and 1 patient developed an umbilical hernia, which was surgically corrected. Of the patients who developed brid ileus, 3 underwent conservative correction and one underwent surgical correction.
\end{abstract}

Conclusion: Thoracoport-assisted laparoscopic appendectomy is a minimally invasive method, and we recommend to use with its advantages such as cosmetics, cost, easy surgical procedures, pain, shorter length of hospital stay and low complication rate.

Keywords: Thoracoport, appendectomy, laparoscopi, children.

\section{GíRIŞ}

Apandisit, apendiks vermiformisin enflamasyonudur ${ }^{1}$ ve çocuklardaki en slk cerrahi karın ağrısı sebebidir ${ }^{2}$. Tüm yaşam boyunca apandisit gelişimi \%7-8 arasındadır ve genç yaşlarda en yüksek pik insidansına sahiptir $^{3}$. Apendektomi, akut apandisit için etkili ve güvenli bir tedavi seçeneği olarak kabul edilir. Açlk ve laparoskopik olarak standart iki yaklaşım vardır. Günümüzde apandisitli olguların dörtte üçünün laparoskopik olarak yapıldığı bildirilmiştir. Laparoskopik apendektomi hastanede yatış süresinin kısa olması, daha az postoperatif ağrı, hızlı iyileşme, iyi kozmetik sonuçları, daha iyi görüş ile diğer patolojilerin tesbit üstünlüğü ve düşük yara enfeksiyonu gibi avantajları sebebiyle günümüzde birçok merkezde standart bir yaklaşım haline gelmiştir4-10. Buna karşılık maliyetlerinin yüksek olması, ameliyat süresinin daha uzun sürmesi, cerrahi beceri ve ekipman gibi bazı dezavantajlarıda mevcuttur ${ }^{11-13}$. Laparoskopik cerrahi ilk zamanlarda multiport olarak başlanmıștır. Daha sonra 1992'de Pelosi tarafindan ilk olarak apendektomide single insizyon laparoskopik cerrahi (SILS) uygulanmıștır ${ }^{14}$. Bu yöntemin multiport laparoskopiye göre daha az postoperatif ağrı, yara komplikasyonu, hızlı iyileşme ve iyi kozmetik sonuçları olduğu bildirilmiştirit-16. Ancak tek port için kullanılan malzemeler ve el aletlerin pahalı olması ve cerrahın deneyimi bu yöntemin dezavantajıdır.

Çalışmamızda açık, klasik multiport laparoskopi ve single insizyon laparoskopik cerrahinin (SILS) dezavantajlarının daha az olduğu torakoport yardımlı laparoskopik appendektomi deneyimlerimizi sunmayı amaçladık. 


\section{YÖNTEMLER}

Çalışmada 2018 Ocak ve 2019 Aralık yılları arasında Dicle Üniversitesi Tıp Fakültesi Hastanesi Çocuk Cerrahi kliniğinde akut apandisit nedeniyle apendektomi yaplan hastaların verileri geriye doğru incelendi. Hastaların cinsiyeti, yaşı, başvuru şikayetleri, tanı yöntemleri, laboratuvar tetkikleri, yapılan işlem, uygulanan tedavi yöntemleri ve hastanede kalış süreleri değerlendirildi. Klinik olarak akut apandisit düşünülen hastalara standart tam kan sayımı, biyokimya, kan grubu ve kanama profili, ayakta direkt batın grafisi (ADBG) ve ultrasonografi (USG) yapıldı. USG' de net olarak ayırt edilemeyen şüpheli bulgular izlenen ve ek patolojiler olabileceği düşünülen hastalara ise kontrastlı Bilgisayarlı Tomografi (BT) istendi. Tanı konulup cerrahi planlanan hastalara iv sivı ve antibiyotik (ampisilin sulbaktam) tedavisi başlandı. Hastalara peroperatif idrar sondası ve NG takıldı. Sonrasında ihtiyaç olmaması durumunda ameliyat sonrasında hasta uyanmadan çıkarıldı. Göbek ortasından longitudinal insizyon ile 11.5 $\mathrm{mm}$ lik toraks trokarı girecek kadar açıldı (Resim 1). Bu trokara eldiven bağlandı ve eldivenin iki parmağı kesilerek 5 mm'lik bir adet kamera ve bir adet çalışma portu girildi (Resim 2). Bu portlardan birisinden hastanın yaşına uygun olarak karbondioksit gazı verilerek pnömoperitoneum oluşturuldu. Tüm hastalara tanısal laparoskopi yapıldı. Apendiks görüldükten sonra atravmatik forseps ile göbekten çıkarılarak apendektomi yapıldı (Resim 3). Apendiks etraf dokulara yapışık ise duruma göre iki yada üçüncü port girilerek apendiks serbestleștirildi ve göbekten çıkarıldı. Cerrahi işlem bittikten sonra göbek anatomisine uygun kapatıldı (Resim 4). Postoperatif hastaların sivı tedavisine ve antibiyotiğe devam edildi. Hastalar aynı gün mobilize edildi. 1 gün sonra hastanın kliniği uygunsa oral başland. Takiplerde herhangi bir problemi olmayan hastalar önerilerle taburcu edildi. Bir hafta sonra patoloji sonuçları ile kontrole çağırıldılar. Oluşan komplikasyonlar kaydedildi. Çalışmamıza ameliyata açık cerrahi ile başlanan akut apandisitli hastalar ve tanı esnasında perfore apandisit düşünülen hastalar dahil edilmedi. Çalışmamız Dicle Üniversitesi Tıp fakültesi girişimsel olmayan klinik araștırmalar etik kurulundan onay almıştır. (Tarih:16-7-2020 Karar No:233).

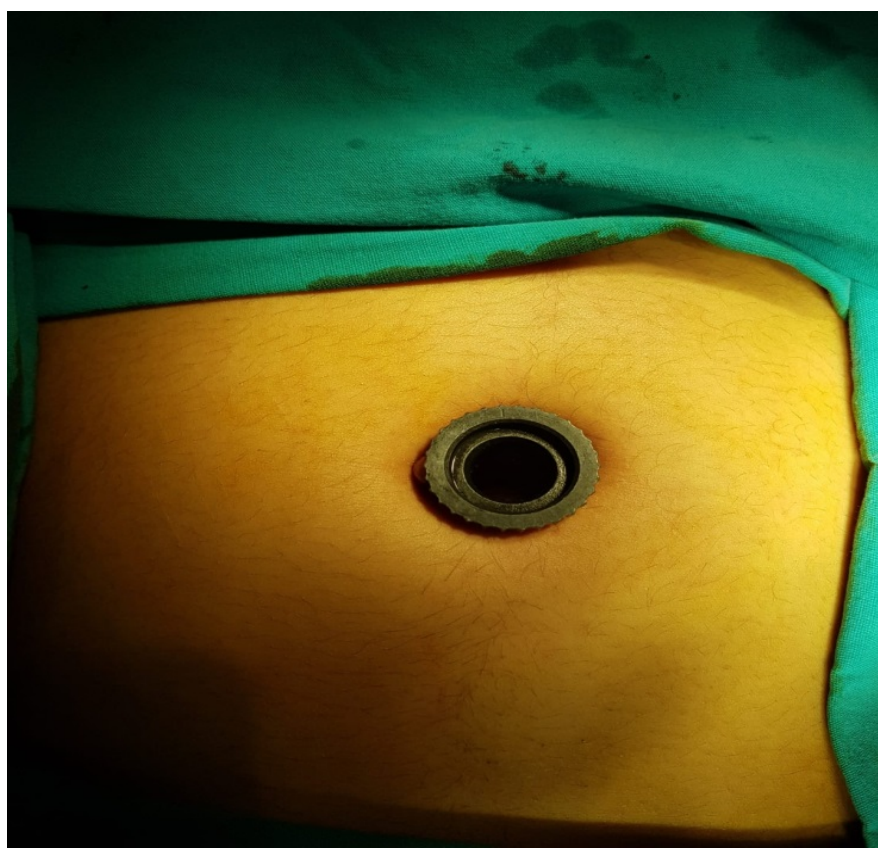

Resim 1: Torakoportun göbekten yerleștirilmiş görünümü

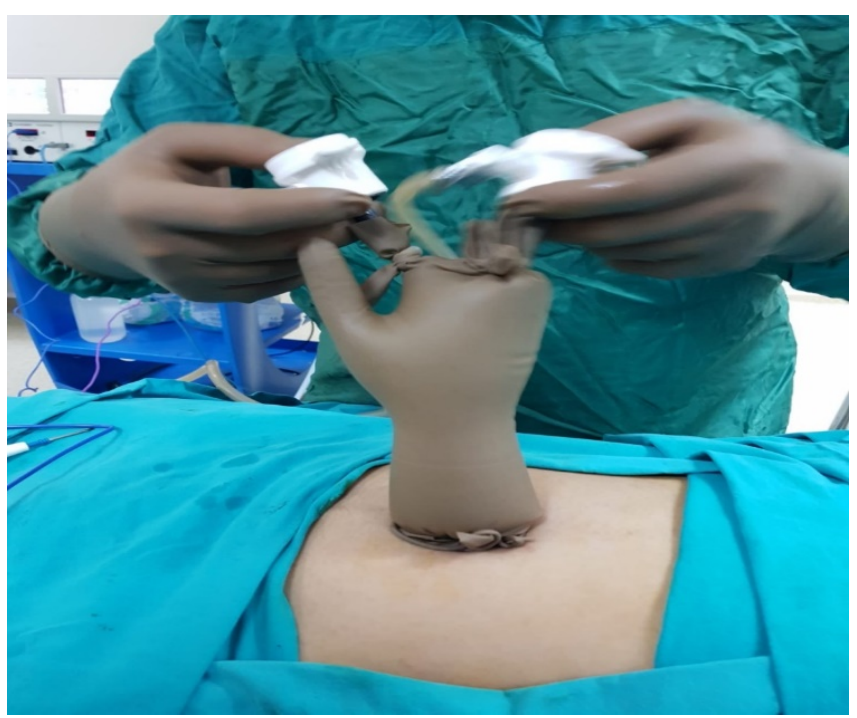

Resim 2: Torakoport yardımlı laparaskopik apendektomi için hazırlanan sistem 


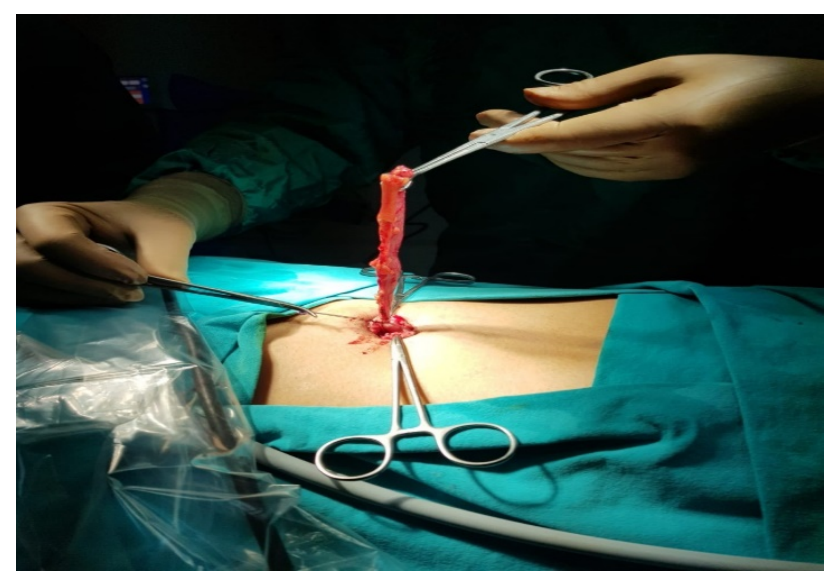

Resim 3: Apendiksin göbekten çıarılarak ekstrakorporeal olarak apendektomi yapılması

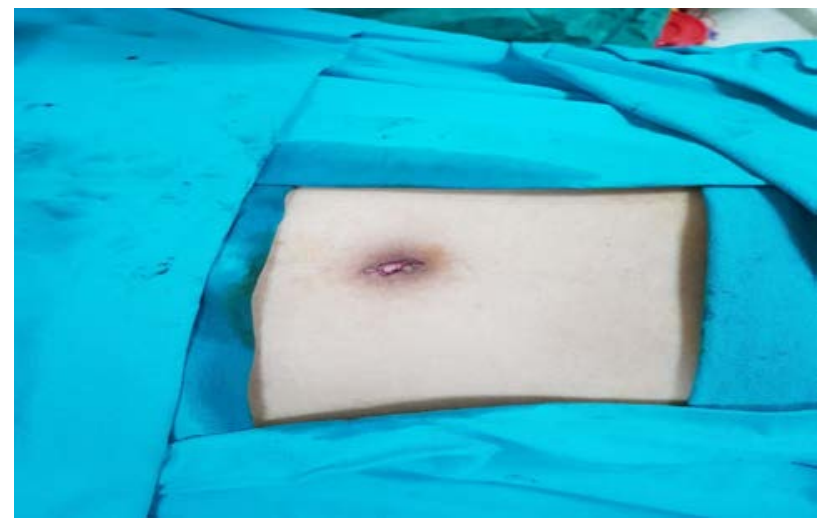

Resim 4: İşlem sonrası operasyon bölgesi

Araştırma verilerimizin istatistiksel değerlendirmesinde IBM SPSS 21.0 for windows istatistik programı kullanıldı. Ölçümsel sürekli değişkenler ortalama \pm standart sapma (SD) ile, kategorik değişkenler sayı ve yüzde (\%) ile sunuldu.

\section{BULGULAR}

Çalışmamızda 177'si $(\% 63,7)$ erkek, 101'i $(\% 36,3)$ kız olmak üzere toplam 278 hasta vardı. Hastaların yaş ortalaması ortalama 11.6 (2-17) idi. Hastaların başlıca semptomları: Karın ağrısı \%93.1(n:260), iştahsızlık \%79,1 (n:220), bulantı \%26,9 (n:75), kusma \%16,9 (n:47) ve ateş \%4 (n:12) idi.

Hastaların laboratuar tetkiklerinde ortalama beyaz küre 17.05 (4.3-22.4) idi (Normal değer: 3.7-10.1 $1000 / u L)$. İki yüz dokuz $(\% 75,2)$ hastanın WBC si yüksekti. Hastaların ortalama C Reaktif Protein (CRP) değerleri 3.03 (0-14.69) idi (Normal değer:0-
$0.5 \mathrm{mg} / \mathrm{dl})$. CRP yüksekliği $218(\% 78,4)$ hastada tespit edildi.

Bütün hastaların USG'si değerlendirildi. USG' de 235 (\%84) hastada anlamlı bulgular izlendi. BT çekilen 16 hastanın ise 14 'ünde $(\% 5,03)$ apandisitle uyumlu bulgular izlendi. Geri kalan 29 hasta ise klinik ve fizik muayene bulguları ile cerrrahi kararı verilerek opere edildi.

Hastaların tamamina ameliyatta torakoport yardımlı laparoskopi ile başlandı. 250 (\%89.2) hastada işlem torakoport yardımlı laparoskopik apendektomi olarak tamamlandı. Beş hastada 2. port, 10 hastada 3. port ihtiyacı oldu. Laparoskopik işlem 13 hastada sonlandırıldı ve açık cerrahiye geçildi. Açık cerrahiye geçilme nedeni yapışıklık, apendiksin retroçekal ve anatomik olarak zor yerleşimli olması idi.

Tablo I : Hastaların demografik verileri

\begin{tabular}{|c|c|c|c|}
\hline & HASTA SAYISI & TOPLAM & 278 \\
\hline & CINSIYYT & $\begin{array}{l}\text { ERKEK } \\
\text { KIZ }\end{array}$ & $\begin{array}{l}177(\% 63,7) \\
101(\% 36,3)\end{array}$ \\
\hline & YASS & & $11.6(2-17)$ \\
\hline LABORATUAR & $\begin{array}{l}\text { WBC } \\
\text { CRP }\end{array}$ & $\begin{array}{l}\text { NORMAL } \\
\text { YÜKSEK } \\
\text { NORMAL } \\
\text { YÜKSEK }\end{array}$ & $\begin{array}{l}69(\% 24,8) \\
209(\% 75,2) \\
60(\% 21,6) \\
218(\% 78,4)\end{array}$ \\
\hline RADYOLOJİ & $\begin{array}{l}\text { USG } \\
\text { BT }\end{array}$ & $\begin{array}{l}\text { NORMAL } \\
\text { ANLAMLI } \\
\text { NORMAL } \\
\text { ANLAMLI }\end{array}$ & $\begin{array}{l}43(\% 15,4) \\
235(\% 84,6) \\
2 \\
14(\% 5,03)\end{array}$ \\
\hline CERRAHİ & & $\begin{array}{l}\text { SINGLE PORT } \\
\text { 2-3 PORT } \\
\text { AÇIK CERRAHİ }\end{array}$ & $\begin{array}{l}250(\% 89,2) \\
15(\% 5,3) \\
13(\% 4,67)\end{array}$ \\
\hline PATOLOJİ & & $\begin{array}{l}\text { LENFOID } \\
\text { HIPERPLAZI } \\
\text { AKUT APANDISIT }\end{array}$ & $\begin{array}{l}21(\% 7,6) \\
257(\% 92,4)\end{array}$ \\
\hline KOMPLIKKASYON & & $\begin{array}{l}\text { VAR } \\
\text { YOK }\end{array}$ & $\begin{array}{c}8(\% 2,9) \\
270(\% 97,1)\end{array}$ \\
\hline
\end{tabular}


Patoloji sonucuna göre $257(\% 92,4)$ hastada apandisitle uyumlu bulgular izlendi. Hastaların ortalama yatış süresi 1.7 (1-4) gün idi. Komplikasyon olarak 4 hastada brid ileus, 3 hastada yara yeri enfeksiyonu, 1 hastada umblikal herni geliști ve cerrahi olarak düzeltildi. Brid ileus gelişen hastaların 3'ü konservatif olarak, birisi cerrahi olarak düzeltildi. Kaybedilen hasta olmadı. Hastaların demografik verileri Tablo I' de verilmiştir.

\section{TARTIŞMA}

Apandisitin nedeni ve apendiksin işlevi hala büyük ölçüde bilinmemektedir. Normal bağırsak florası için bir rezervuar görevi gördüğu ve bağırsakta anatomik olarak en yüksek lenfoid doku konsantrasyonuna sahip yer olduğu düşünülmektedir. Apendektomi yapılan hastalarda ülseratif kolit riskinin azaldığını ve tekrarlayan Clostridium difficile ile ilişkili kolit riskinin arttığını bildiren yayınlar mevcuttur ${ }^{17,18}$. Çocuklarda apandisit, akut karın ağrısının en sık nedenlerinden biridir. Etyolojisinde lenfoid hiperplazi, apandisit lümeni obliterasyonu, apendiksin anatomik olarak ince ve uzun olması dahil birçok faktör ile ilișkilidir ${ }^{19}$.

Noh H. ve ark. çalışmalarında apandisitli hastaların \%61'inin erkek ve \% 39'unun kiz olduğunu bildirmişler ${ }^{20}$. Arslan S. ve ark. çalışmasında hastaların \%63' ü erkek ve \%37'si kız hasta olarak belirtilmiş²1. Pogoreliç Z. ve ark. çalışmasında 834 hastanın \%62'si erkek cinsiyet olarak belirtmişler ${ }^{8}$. Bizim çalışmamızda da literatürle uyumlu olarak hastaların \%63,7 si erkek \%36,3 ü kı idi.

Apandisit en yüksek oranda hayatın ikinci on yılında ortalama 10-11 yaş arasında görülür22. Pogoreliç Z. ve ark. apandisitli hastaların ortalama yaşını 13 olarak bulmuşlar ${ }^{8}$. Arslan S. ve ark. çalışmaların da ortalama yaşı 10.8 olarak tespit etmişler ${ }^{21}$. Başka çalışmalarda da 10-19 yaşları arasında pik yaptığını bildiren çalışmalar mevcuttur ${ }^{17}$. Bizim çalışmamızda hastaların yaş ortalaması 11.5 (2-17) idi. Bu bulgular literatürle uyumlu olarak gözlendi.

Apandisitin tanısında hiçbir laboratuvar testinin spesifikliği yoktur. Ancak WBC, ANC (absolute neutrophil count) ve CRP apandisiti tahmin etmek için geniş aralıkta bir duyarlılığa sahiptir. Siddique K. ve ark. çalışmasında akut apandisitte WBC duyarlılık oranını \%80,5 olarak belirtilmiş ${ }^{23}$. CRP değerlerinin ise duyarlılık oranını akut apandisitte \%75,0 olarak bildirmişlerdir. Bizde çalışmamızda WBC ve CRP düzeylerini değerlendirdik. WBC düzeyinin $\% 75$ hastada, CRP düzeyinin ise $\% 78$ hastada anlamlı olarak yüksek olduğunu tespit ettik.

Akut apandisitte laparoskopi cerrahi işlem öncesi hem tanısal hem de tedavi amaçlı yapılmaktadır. Laparoskopik apendektomi açık yönteme göre, azalmış analjezik gereksinimi, daha kısa hastanede kalış, azalmış yara enfeksiyonu insidansı, ileus ve bağırsak tıkanması riskinin daha az olması, daha az ağrı, daha iyi kozmetik sonuçlar olması sebebiyle standart yaklaşım haline gelmiştir6,24.

Minimal invaziv cerrahinin yaygınlaşması ile birlikte laparoskopik cerrahi ile yapılan cerrahiler popüler hale gelmeye başlamıştır. Ancak single insizyon laparoskopinin en önemli dezavantajı kullanılan cerrahi malzemelerin pahalı olması olmasıdır. Dolayısıyla günümüz şartlarında maliyetleri düşürmek için farklı yöntemler uygulanmaktadır ${ }^{25}$.

Bizim çalışmamızda uygun maliyet ve yapılan cerrahi işlemin kolay olması nedeni ile hem hastalar hemde cerrahi ekip için bir avantaj sağlanmaktadır. Torakoport yardımlı laparoskopide eldiven, toraks trokarı ve konvansiyonel el aletleri kullanılmaktadır. $\mathrm{Bu}$ yüzden maliyet diğer yöntemlere göre oldukça uygundur. Ayrıca bu yöntemde apendiks göbekten çlkarılarak geleneksel apendektomi yapıldığı için hem kolay hemde kısa sürede tamamlanmaktadır. Böylece standart multiport ve single insizyon laparoskopilerin maliyet, 
süre ve deneyim gibi dezavantajları çalışmamızda daha makuldur.

Açık apendektomi yapılan hastalarda belirgin bir insizyon skarı görünmektedir. Klasik multiport laparoskopik apendektomide karnın farklı yerlerinden port girişlerine ait insizyon skarları görünmektedir. Torakoport yardımlı laparoskopik cerrahide giriş yerimiz göbeğin içinde kalmaktadır. Dolayısı ile iyileştikten sonra iyi bir kozmetik görünüm elde edilmektedir.

Hernandez-Martin ${ }^{26}$ S. ve ark. yaptıkları çalışmada hastaların \%10,4 ünde, Sesia ${ }^{27}$ ve ark. çalışmalarında \%14,1, Ohno $^{28}$ ve ark. çalışmalarında \%16,8 ek port ve açık cerrahiye dönüş olarak rapor edilmiştir. Bizim çalışmamızda ise $250(\% 89,2)$ hastada işlem tek port olarak bitirildi. Onbeş $(\% 5,3)$ hastada 2 . yada 3. port gereksinimi oldu. On üç hastada ise laparoskopik işlem sonlandırıldı ve klasik açık apendektomi ile işlem bitirildi. Bu bulgularımız literatürle uyum göstermektedir.

Dong BK. ve ark.tarafından yapılan çalışmada SILS uygulanan grubun ameliyat sonrası yatış süreleri $4.0 \pm 1.5$ gün ve klasik laparoskopik appendektomi uygulanan grubun $3.8 \pm 2.0$ gün idi. Hastanede yatış süresi arasında iki yöntem arasında istatistiksel olarak anlamlı bir fark olmadığını bildirmişler ${ }^{25}$.

Bizim çalışmamızda ise ameliyat sonrası hastanede yatış süresi 1.7 (1-4) olarak diğer çalışmalardan düşük tespit edilmiştir.

Lıu Y. ve ark. çalışmalarında açık ve laparoskopik apendektomi yapılan hastaları karşılaştırmışlar. Perforasyon, apse, apandisit nüksü ve yara enfeksiyonu majör komplikasyonlar olarak antibiyotikle ilişkili döküntü, ateş, ishal, kusma ve paralitik ileus gibi minör komplikasyonlar olarak kaydedildi. Majör komplikasyonların açık yapılan hastalarda anlamlı olarak daha yüksek olduğunu tespit etmişler. Minör komplikasyon olarak paralitik ileus ve diarenin laparoskopik gurupta açık yapılan guruba oranla daha fazla izlendiğini kaydetmişler. Laparoskopik yapılan grupta \%9,5 yara enfeksiyonu, \%2,6 recurrens ve $\% 1$ 'inde abse tespit etmişler ${ }^{7}$. Laparoskopik ve açık apendektomi yapılan bir başka çalışmada ise yara enfeksiyonu, abse ve ileusun açık yapılanlarda daha fazla olduğu ve laparoskopi yapılan bir hastada ise insizyon bölgesinde kanama tespit edilmiş ${ }^{8}$. Bizim çalışmamızda komplikasyon olarak 4 hastada brid ileus, 3 hastada yara yeri enfeksiyonu, 1 hastada uzun evrede umblikal herni geliști. Brid ileus gelişen 3 hasta medikal tedavi ile bir hastada cerrahi olarak düzeltildi. Umblikal herni onarıldı. Biz çalışmamızda komplikasyon oranını literatüre göre daha düşük tespit ettik.

\section{SONUÇ}

Torakoport yardımlı laparaskopik apendektomi minimal invaziv bir yöntem olup kozmetik, maliyet, cerrahi işlemin kolaylığı, ağrı, hastanede yatış süresinin azlığı ve düşük komplikasyon gibi avantajları ile kullanılmasını önermekteyiz.

Etik Kurul Onayı: Bu çalışma Dicle Üniversitesi Tıp fakültesi girişimsel olmayan klinik araştırmalar etik kurulundan onay almıştır. (Tarih:16-7-2020 Karar No:233) Çalışma Helsinki Deklarasyonu'na uygundur.

Çıkar Çatışması Beyanı: Yazarlar çıkar çatışması olmadığını bildirmişlerdir.

Finansal Destek: $\mathrm{Bu}$ çalışma herhangi bir fon tarafından desteklenmemiştir.

Declaration of Conflicting Interests: The authors declare that they have no conflict of interest.

Financial Disclosure: No financial support was received.

\section{KAYNAKLAR}

1. Karabulut R, Sonmez K, Turkyilmaz Z, et al. Negative appendectomy experience in children. Ir J Med Sci 2011; 180: 55-8. 
2. Deng Y, Chang DC, Zhang Y, et al. Seasonal and day of the week variations of perforated appendicitis in US children. Pediatr Surg Int 2010; 26: 691-6.

3. Addiss DG, Shaffer N, Fowler BS, et al. The epidemiology of appendicitis and appendectomy in the United States. Am J Epidemiol 1990; 132: 91025.

4. Bhangu A, Richardson C, A Torrance A. et al. National Surgical Research Collaborative. Multicentre observational study of performance variation in provision and outcome of emergency appendicectomy. Br J Surg. 2013; 100: 1240-52.

5. Brugger L, Rosella L, Candinas D, Guller U. Improving outcomes after laparoscopic appendectomy: A population based, 12-year trend analysis of 7446 patients. Ann Surg. 2011; 253: 30913.

6. Stringer MD. Acute appendicitis. J Paediatr Child Health. 2017; 53: 1071-6.

7. Liu Y, Cui Z, Zhang R. Laparoscopic versus open appendectomy for acute appendicitis in children. Indian Pediatrics. 2017; 54: 938-41.

8. Pogorelic Z, Kostovski B, Jeroncic A, et al. A comparison of endo loop ligatures and non absorbable polymeric clips for the closure of the appendicular stump during laparoscopic appendectomy in children. J Laparoendosc Adv Surg Tech A. 2017; 27: 645-50.

9. Biondi A, Di Stefano C, Ferrara F, et al. Laparoscopic versus open appendectomy: A retrospective cohort study assessing outcomes and costeffectiveness. World J Emerg Surg. 2016; 11: 44.

10. Çiftçi F. Laparoscopic vs mini-incision open appendectomy. World J Gastrointest Surg. 2015; 7: 267-72.

11. Michailidou M, Goldstein SD, Sacco Casamassima MG, et al. Laparoscopic versus open appendectomy in children: the effect of surgical technique on healthcare costs. Am J Surg 2015; 210: 270-5.

12. Ukai T, Shikata $S$, Takeda $H$, et al. Evidence of surgical outcomes fluctuates over time: results from a cumulative meta-analysis of laparoscopic versus open appendectomy for acute appendicitis. BMC Gastroenterol 2016; 16: 37.
13. Hermans BP, Otte JB. Laparoscopic appendicectomy: pros \& cons-literature review of 4190 cases. Acta Chir Belg 1997; 97: 110-17.

14. Frutos MD, Abrisqueta J, Lujan J, et al. Randomized prospective study to compare laparoscopic appendectomy versus umbilical singleincision appendectomy. Ann Surg. 2013; 257: 4138.

15. Carter JT, Kaplan JA, Nguyen JN, et al. A prospective, randomized controlled trial of singleincision laparoscopic vs conventional 3-port laparoscopic appendectomy for treatment of acute appendicitis. J Am Coll Surg. 2014; 218: 950-959.

16. Liang HH, Hung CS, Wang W, et al. Single-incision versus conventional laparoscopic appendectomy in 688 patients: a retrospective comparative analysis. Can J Surg. 2014; 57: 89-97.

17. Bhangu A, Søreide K, Di Saverio S, et al. Acute appendicitis: modern understanding of pathogenesis, diagnosis, and management. Lancet 2015; 386: 1278-87.

18. Sanders NL. Appendectomy and Clostridium difficile colitis: relationships revealed by clinical observations and immunology.World J Gastroenterol 2013; 19: 5607.

19. Başaklar AC, Türkyılmaz Z. Karın agrisi ve akut apandisit, In: Başaklar AC (ed), Bebek ve Çocukların Cerrahi ve Ürolojik Hastalıkları. Palme Yayıncılık, Ankara, 2006; 991-1013.

20. Noh H, Chang SJ, Han A. The diagnostic values of preoperative laboratory markers in children with complicated appendicitis. J Korean Surg Soc 2012; 834: 237-41.

21. Arslan S, Aydogdu B, Arslan MŞ, et al. Analysis of Risk Factors for Appendicitis in Children: A Multicenter Epidemiological Study. Dicle Tıp Dergisi. 2016; 556-60.

22. Rentea RM, Peter SDS, Snyder CL. Pediatric Appendicitis: State of the Art Review. Pediatr Surg Int. 2017; 269-83.

23. Siddique $K$, Baruah $P$, Bhandari $S$, et al. Diagnostic accuracy of white cell count and Creactive protein for assessing the severity of paediatric appendicitis. JRSM Short Rep. 2011; 2: 59. 
24. Burjonrappa SC, Nerkar H. Teaching singleincision laparoscopic appendectomy in pediatric patients. JSLS 2012; 16: 619-22.

25. Dong BK, Lee SH, Lee SY, et al. Application of Single Incision Laparoscopic Surgery for Appendectomy in Children. J Korean Surg Soc.2012; 110-5.

26. Hernandez-Martin S, Ayuso L, Yessenia Molina A. Transumbilical laparoscopic-assisted appendectomy in children: is it worth it? Surg Endosc. 2017: 5372-80.
27. Sesia SB, Berger E, Holland-Cunz S, Mayr J, Hacker FM. Laparoscopy-assisted single-port appendectomy in children: safe alternative also for perforated appendicitis? Medicine (Baltimore) 2015; 94: e2289.

28. Ohno Y, Morimura T, Hayashi S. Transumbilical laparoscopically assisted appendectomy in children: the results of a single-port, single-channel procedure. Surg Endosc 2012; 26: 523-7. 